
Neth. J. Pl. Path. 96 (1990) 29-34

\title{
Effects of powdery mildew and weather on winter wheat yield. 1. Variation of weather between years
}

\author{
R.A. DAAMEN ${ }^{\prime}$ and I.T.M. JORRITSMA ${ }^{2 *}$ \\ 1 Research Institute for Plant Protection (IPO), P.O. Box 9060, $6700 \mathrm{GW}$ Wageningen, the \\ Netherlands \\ ${ }^{2}$ Department of Theoretical Production Ecology (TPE), Agricultural University, P.O. Box 430, \\ $6700 \mathrm{AK}$ Wageningen, the Netherlands
}

Accepted 9 October 1989

\begin{abstract}
A vital question to upgrade disease management systems is whether damage functions, established in years with specific weather conditions, can be applied also in other years. A simulation approach was used to explore effects of weather on yield and damage. Two existing models of wheat and a third, a combination of both, were used to compute yield, first in absence of mildew. In a second paper, effects of mildew will be reported. Yields simulated for different years were not significantly correlated with yields harvested, adjusted for their increase over years, in the Netherlands. Differences in performance between the models could be attributed to the method of simulating development and growth early in the cropping season.
\end{abstract}

Additional keywords: Triticum aestivum, simulation, SUCROS87, NWHEAT.

\section{Introduction}

The averaged measured damage function of powdery mildew in winter wheat (Daamen, 1988 and 1989) was implemented in a management system to assess the profitability of fungicide application in farmers' fields in the Netherlands. Though damage was measured under conditions approaching those of farmers' fields, it is uncertain to what extent this damage function may be extrapolated to other weather conditions (Jenkyn, 1984), in different years or locations, and to crop husbandry practices other than those of the experiments. Repeated measurements in other years and locations may answer this question, but will not develop general methods to enable these extrapolations to be made. The study of physiological processes which underlay damage, provide another option to answer the question.

The physiology of the host is changed by a mildew infection. Photosynthesis at light saturion, especially, drops rapidly after inoculation. This decrease is not correlated with the chlorophyll content of infected leaves (Allen, 1942), but is correlated with a decrease

* Present address: Dorschkamp Research Institute for Forestry and Urban Ecology, P.O. Box 23, 6700AA Wageningen, the Netherlands 
in activity and amount of the ribulose biphosphate carboxylase protein and changes in the ef fectiveness of other enzymes (Walters and Ayres, 1984). Rabbinge et al. (1985) quantified the effect of powdery mildew on photosynthesis of wheat leaves in relation to light intensity. They found that, even at low levels of infection, the assimilation rate at light saturion was considerably reduced, while the light use efficiency and dark respiration were not significantly affected. These quantified physiological processes can provide a general method to assess the effect of weather on damage by powdery mildew.

In this paper the effect of weather on yield is studied. The performance of two crop models and a combination of both, to varying weather conditions is compared with wheat yields harvested in the Netherlands in different years. In a following paper (Daamen \& Jorritsma, 1990), the simulation of yield in relation to varying mildew intensities and weather conditions will be discussed.

\section{Materials and methods}

Crop models. Two models, with estimates of parameter values under conditions in the Netherlands, were available: NWHEAT (version date: December 1986, Groot, 1987) and SUCROS87 (version date: November 1987, Spitters et al., 1989).

NWHEAT was developed to simulate the growth and development of winter wheat from temperature and radiation after sowing date, taking into account the nitrogen and water balance in crop and soil. As this model was too complex for our purpose, J.R.R. Groot kindly adapted it so that water and nitrogen were not limiting. Nitrogen still played an important role as it governs photosynthesis and death of leaves.

SUCROS87, a summary model, was developed to simulate growth and development when water and nitrogen are not limiting and growth is governed by temperature and radiation. The model, written in the language CSMP, was translated into FORTRAN77. The SUCROS87 model for winter wheat starts on 1 January.

SUCROS87E, an extended version of SUCROS87 simulates growth from sowing date onwards. Development (D) is simulated, depending on photoperiod and temperature (Groot, 1987; Reinink et al. 1986). Before a developmental stage $(D)$ of 0.5 and a leaf area index $(L)$ of 1.5 , the daily growth of the leaf area index $(\delta L)$ is computed from the daily growth of the shoot weight $\left(\delta W_{\mathrm{th}}\right)$ corrected for the daily loss of weight by leaf death $\left(\delta W_{\mathrm{kl}}\right)$, multiplied by the average specific leaf area $\left(l_{\mathrm{\psi}}\right)$ :

$$
\delta L=l_{\mathrm{sp}} \cdot\left(\delta W_{\mathrm{sh}}-\delta W_{\mathrm{ld}}\right) ; \quad D<0.5 \text { and } L<1.5
$$

Although this conforms with the approach of SUCROS (Van Keulen et al., 1982) and of NWHEAT, NWHEAT and SUCROS87 differ in many aspects (Groot, 1987; Spitters et al., 1989).

To compare the response of SUCROS87E, SUCROS87 and NWHEAT, to wheather conditions, yields were simulated with the models without disease, using actual weather from Wageningen in 1975 to 1986, and a sowing date of 20 October. National average yields (statistical yearbook), yields obtained in the intensive cropping treatment of cultivar trials on marine clay soils (RIVRO Institute), and yields on best fields on the farm 'De Bouwing' near Wageningen (pers. comm. W. de Jager) were used as estimates of harvested yield in these years. Correlations among the yields were calculated and used to compare the yields over the eleven years. As harvested yields improved gradual- 
ly, they were regressed on simulated yields and year, to calculate the partial regression coefficients between harvested and computed yields.

\section{Results}

Performance of the models without disease. Average yields computed by SUCROS87 and by NWHEAT were about the same (Table 1). Those of SUCROS87E were about one ton ha ${ }^{-1}$ higher. The models computed equal variation in yield over the years. Yields computed by NWHEAT and SUCROS87E were significantly correlated, but they were not correlated with those of SUCROS87 (Table 2). SUCROS87 and SUCROS87E differ only in the computation of development and growth early in the season. NWHEAT and SUCROS87E differ in many aspects, but not in the computation of development early in the season. Therefore, the difference in performance of NWHEAT and SUCROS87 is attributed to the method of simulating early growth.

The estimates of harvested yield were significantly correlated and increased significantly over the years, due to the gradually intensifying crop husbandry (Tables 1 and 2). The correlation coefficients between the yields harvested and computed were not significant (Table 2). Also the partial regression coefficients between yields harvested and computed, adjusted for a constant annual increase, were not significant (Table 3). Therefore, the models do not explain the variation in harvested yield between years.

Table 1. Comparison of harvested and computed yields ( $k g$ dry weight are $\left.{ }^{-1}\right)$ in different years, at a simulated sowing date of 20 October.

\begin{tabular}{|c|c|c|c|c|c|c|}
\hline \multirow[t]{2}{*}{ Year } & \multicolumn{3}{|c|}{ Harvested yield } & \multicolumn{3}{|c|}{ Computed yield } \\
\hline & $\begin{array}{l}\text { country } \\
\text { average }\end{array}$ & $\begin{array}{l}\text { cultivar } \\
\text { trials }^{\prime}\end{array}$ & $\begin{array}{l}\text { De } \\
\text { Bouwing } 2\end{array}$ & SUCROS87 & NWHEAT & SUCROS87E \\
\hline $75-76$ & 48. & 62.7 & 52.9 & 63.8 & 54.5 & 63.8 \\
\hline $76-77$ & 45. & 59.1 & 60.5 & 89.5 & 72.0 & 84.7 \\
\hline $77-78$ & 57. & 66.5 & 68.0 & 72.6 & 83.4 & 104.3 \\
\hline $78-79$ & 51. & 62.3 & 61.3 & 69.2 & 81.4 & 91.7 \\
\hline $79-80$ & 54. & 63.3 & 71.4 & 79.6 & 72.4 & 88.9 \\
\hline $80-81$ & 58. & 71.9 & 73.9 & 67.3 & 76.0 & 87.0 \\
\hline $81-82$ & 64. & 79.2 & 68.0 & 71.7 & 74.8 & 87.3 \\
\hline $82-83$ & 60. & 73.6 & 78.1 & 84.6 & 72.4 & 80.4 \\
\hline $83-84$ & 66. & 79.7 & 98.3 & 60.9 & 78.3 & 90.9 \\
\hline $84-85$ & 56. & 62.2 & 74.8 & 82.9 & 80.6 & 92.2 \\
\hline $85-86$ & 68. & 79.6 & 91.6 & 81.2 & 73.5 & 85.1 \\
\hline Average & 57. & 69.1 & 72.6 & 74.8 & 74.5 & 86.9 \\
\hline $\mathrm{CV} \% 0^{3}$ & 12.7 & 11.5 & 18.3 & 12.3 & 10.4 & 11.3 \\
\hline
\end{tabular}

1 On marine clay soils, treatment: intensive cropping.

2 Best yielding fields on the farm.

${ }^{3}$ Coefficient of variation.

Neth. J. Pl. Path. 96 (1990) 
Table 2. Correlation coefficients of harvested and computed yields, $d f=9$. Correlations with yields of 'De Bouwing' were with actual sowing dates. Underlined coefficients are significant at $p<0.05$.

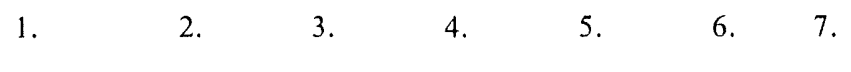

1. Year

2. Country average

$-$

3. Cultivar trials

$\underline{0.83}$

4. De Bouwing

$\overline{0.66}$

5. SUCROS87

$\underline{0.84}$

6. NWHEAT

0.16

7. SUCROS87E

0.38

0.22

$$
\begin{array}{r}
\overline{0.93} \\
-\underline{0.85} \\
-0.18 \\
0.35 \\
0.29
\end{array}
$$

$\begin{array}{rr}\overline{0.74} & - \\ -\overline{0.28} & -0.04 \\ 0.13 & 0.35 \\ 0.05 & 0.30\end{array}$

$0 . \overline{10}$

\begin{tabular}{|c|c|c|c|}
\hline \multirow[b]{2}{*}{ Harvested yields } & \multicolumn{3}{|c|}{ Computed yiclds' } \\
\hline & SUCROS87 & NWHEAT & SUCROS87E \\
\hline Country average & $-0.24 \quad(0.13)$ & $(0.20)$ & $(0.15)$ \\
\hline Cultivar trials & $-0.33 \quad(0.19)$ & -0.15 & -0.08 \\
\hline 'De Bouwing' & $-0.24 \quad(0.25)$ & $0.14 \quad(0.34)$ & $(0.24)$ \\
\hline
\end{tabular}

$0.08 \quad \underline{0.94}$

Table 3. Partial regression coefficients ( $\mathrm{kg}$ harvested per $\mathrm{kg}$ computed), of threc different data sets of harvested yield, adjusted for a constant annual increase, with yields computed by three different models, see text. Standard errors are given between brackets.

1 Simulated sowing date of 20 October or actual sowing date of 'De Bouwing'.

\section{Discussion}

An indication was obtained that the effect of weather on yield was not computed accurately by the models. Computed yields varied considerably between years, due to the varying weather conditions. Also, harvested yields varied considerably and the question is whether this variation should be attributed to weather or to other yield constraints. Harvested yields were at least partly limited by these other constraints, such as diseases, pests, lodging and fertilizer shortages, as harvested yields increased over years due to the gradually intensifying crop husbandry. The question then is whether the variation in harvested yields between years, corrected for an annual trend was caused by weather or by other varying constraints.

Harvested yields, in the cultivar trials and on 'De Bouwing', were in later years often higher than computed yields, in which cases it is unlikely that other yield constraints than weather dominate. Moreover, the three data sets of harvested yields were positively correlated, also after correction for trend, which indicates that the constraints of yields were similar. This suggests that the variation in harvested yields was dominated by weather.

Computed yields depended on the method of simulating development and growth 32

Neth. J. Pl. Path. 96 (1990) 
early in the cropping season. Therefore, it might be necessary to give more attention to the computation of the partitioning of assimilates between root and shoot, and of the specific leaf area, in dependence of temperature (Van Dobben, 1962).

\section{Acknowledgements}

We are grateful to professors R. Rabbinge and J.C. Zadoks, and Dr C.J.T. Spitters for comments on the manuscript.

\section{Samenvalting}

Effecten van meeldauw en weersomstandigheden op opbrengsten van wintertarwe. 1. Verschillende weersomstandigheden per jaar

Om systemen voor geleide bestrijding van ziekten te verbeteren, werd de vraag gesteld of schaderelaties, vastgesteld in jaren met specifieke weersomstandigheden, ook gebruikt kunnen worden in andere jaren. Twee bestaande modellen van tarwe en een combinatie van beide, werden gebruikt om het effect van weer op opbrengst te berekenen, eerst bij afwezigheid van meeldauw. De berekende opbrengsten in verschillende jaren toonden geen samenhang met de behaalde opbrengsten, gecorrigeerd voor een jaarlijkse toename, in Nederland. Verschillen tussen de modellen konden worden toegeschreven aan de wijze waarop de groei en ontwikkeling van tarwe vroeg in het seizoen wordt berekend.

\section{References}

Allen, P.J., 1942. Changes in the metabolism of wheat leaves induced by infection with powdery mildew. American Journal of Botany 29: 425-435.

Daamen, R.A., 1988. Eflects of nitrogen fertilization and cultivar on the damage relation of powdery mildew (Erysiphe graminis) in winter wheat. Netherlands Journal of Plant Pathology 94: 69-80.

Daamen, R.A., 1989. Assessment of the profile of powdery mildew and its damage function at low disease intensities in field experiments. Netherlands Journal of Plant Pathology 95: 85-105.

Daamen, R.A. \& Jorritsma, I.T.M., 1990. Effects of powdery mildew and weather on winter wheat yield. 2. Effects of mildew epidemics. Netherlands Journal of Plant Pathology 96: 35-46.

Dobben, W.H. van, 1962. Influence of temperature and light conditions on dry-matter distribution, development rate and yield in arable crops. In: Hart, M. (Ed), Fundamentals of drymatter production and distribution. Netherlands Journal of Agricultural Science 10 (No. 5 , special issue): $377-389$.

Groot, J.J.R., 1987. Simulation of crop growth and nitrogen balance in a winter wheat - soil system. CABO report, Wageningen. 38pp.

Jenkyn, J.F., 1984. Elfects of powdery mildew on grain filling in spring barley in contrasting environments. Annals of Applied Biology 105: 195-212.

Keulen, H van, Penning de Vries, F.W.T. \& Drees, E.M., 1982. A summary model for crop growth. In: Penning de Vries, F.W.T \& Laar, H.H. van (Eds), Simulation of plant growth and crop production. Simulation Monographs, Pudoc, Wageningen, 87-94.

Rabbinge, R., Jorritsma, I.T.M. \& Schans, J., 1985. Damage components of powdery mildew in winter wheat. Netherlands Journal of Plant Pathology 91: 235-247.

Reinink, K., Jorritsma, I. \& Darwinkel, A., 1986. Adaptation of the AFRC wheat phenology

Neth. J. Pl. Path. 96 (1990) 
model for Dutch conditions. Netherlands Journal of Agricultural Science 34: 1-13.

Spitters, C.J.T., Keulen, H. van \& Kraalingen, D.W.G. van, 1989. A simple and universal crop growth simulator: SUCROS87. In: Rabbinge, R., Ward, S.A. \& Laar, H.H. van (Eds), Simulation and systems management in crop protection. Simulation Monographs, Pudoc, Wageningen, 147-181.

Walters, D.R. \& Ayres, P.G., 1984. Ribulose bisphosphate carboxylase protein and enzymes of $\mathrm{CO}_{2}$ assimilation in barley infected by powdery mildew (Erysiphe graminis f.sp. hordei). Journal of Phytopathology 109: 208-459. 